\title{
Preparation, Characterization, and Antimicrobial Activities of Mixed Ibuprofen-Salicylic Acid Metal-Drug Complexes
}

\author{
Mercy O. Bamigboye ${ }^{1}$, Ikechukwu P. Ejidike ${ }^{2,3}$, Racheal O. Awolope ${ }^{2}$, Joshua A. \\ Obaleye $^{4}$, and Favour K. Ejimofor ${ }^{5}$ \\ ${ }^{1}$ Department of Industrial Chemistry, Faculty of Physical Sciences, University of \\ Ilorin, Nigeria. obaleye.mo@unilorin.edu.ng \\ ${ }^{2}$ Department of Chemical Sciences, Faculty of Science and Science Education, Anchor \\ University, Lagos, Nigeria. iejidike@aul.edu.ng; rawolope@aul.edu.ng \\ ${ }^{3}$ Department of Chemistry, College of Science, Engineering and Technology, University of \\ South Africa, Florida Campus, South Africa.tejidiip@unisa.ac.za \\ ${ }^{4}$ Department of Chemistry, Faculty of Physical Sciences, University of Ilorin, Ilorin, Nigeria. \\ jobaleye@unilorin.edu.ng \\ ${ }^{5}$ Department of Veterinary Physiology and Pharmacology, Faculty of Veterinary Medicine, \\ University of Nigeria, Nsukka, Nigeria.drfavourruby@gmail.com \\ *Corresponding author,e-mail: iejidike@aul.edu.ng; tejidiip@unisa.ac.za \\ ORCID: https://orcid.org/0000-0002-3643-0198
}

Received 20 Jul 2021, Revised 17 Dec 2021, Accepted 22 Dec 2021, Published Dec 2021

DOI: https://dx.doi.org/10.4314/tjs.v47i5.28

\begin{abstract}
Most variants of bacteria are resistant to traditional antibiotics which are organic. To overcome the growing infections, bacteria resistant infections, and multiple drug resistance (MDR) rates, transition metals with biological importance were coordinated to organic ligands (Ibuprofen and Salicylic acid) with anti-inflammatory properties. In this study, metal complexes of mixed Ibuprofen and Salicylic acid were prepared using a standard method to give of the type $[\mathrm{M}(\mathrm{Ibu})(\mathrm{Sal}) \mathrm{X}]$ (where $\mathrm{M}=\mathrm{Fe}^{2+,} \mathrm{Ni}^{2+}, \mathrm{Cu}^{2+}$, and $\mathrm{X}=\mathrm{Cl}_{2}$, Ibu = Ibuprofen, Sal = Salicylic acid). The complexes were characterized by UV-visible spectroscopy, conductivity measurements, melting points, FT-IR, and X-ray diffraction. The metal ions are coordinated to the ligands via the carboxylato oxygen donor atoms of both ligands. From the physicochemical data, the complexes are non-electrolytes. The XRD study suggested that the metal complexes possess a well-defined crystalline structure with average crystallite sizes of $<62 \mathrm{~nm}$. Evaluations of the antimicrobial activities of the ligands and their complexes against gram-positive bacteria $(S$. aureus, B. subtilis, S. faecalis) and gram-negative bacteria (K. pneumonia, E. coli, and $P$. aeroginosa) via standard method were utilized to determine the zones of inhibition. The complexes exhibited a higher zone of inhibition, indicating higher antimicrobial activities when compared to the parent ligand. The results revealed that the metal-drug complexes are promising chemotherapeutic agents with wide spectrum of activities.
\end{abstract}

Keywords: Metal-drug complexes; Ibuprofen; Spectra studies; Salicylic acid; Antimicrobial activity.

\section{Introduction}

The challenges of multiple drug resistance (MDR) and inadequacies of some organicbased pharmaceutical drugs in the treatments of several diseases; cancer, bacterial infections and viral infections, or pathogenic co-infections have revived the concentration of research into metal-based drugs (Basak et 
al. 2016, Ejidike and Ajibade 2017). Metal ions interact with biomolecules and form covalent bonds owing to their varying oxidation states and coordination numbers (Graf and Lippard 2012). Most metal ions play important roles in maintaining human homeostasis and biological processes. They act as cofactors in the biological functions of proteins, stabilizing, regulating, and completing some cellular functions (Aisen et al. 2001, Andreini et al. 2008, Ejidike and Ajibade 2015). The distribution and transportation of metal ions have been well developed by the human body (Mjos and Orvig 2014). In addition, metal ions can perform catalytic and structural functions (Frezza et al. 2010). Recent advancements in medicines have shown that the therapeutic potencies of several metals ions either alone or in coordination with organic ligands can act against cancer and other pathogenic infections (Storr et al. 2006, Barrios et al. 2013, Ejidike 2018).

Cisplatin, a platinum metal based anticancer drug has been used in the treatments of several cancer models including ovarian, testicular, head and neck, breast, bladder, stomach, prostate, and lung cancers. However, due to some of its side effects, other derivatives of platinum complexes such as carboplatin, oxaliplatin, satraplatin, ormaplatin, aroplatin, enloplatin, zeniplatin, sebriplatin, miboplatin, picoplatin, satraplatin, and iproplatin have been developed, yet they have not shown wide spectra of anticancer activities (Florea and Büsselberg 2011, Ndagi et al. 2017). However, several metals (manganese, antimony, boron, ruthenium, gallium, germanium, gold, molybdenum, arsenic, nickel, niobium, cobalt, platinum, palladium, rhodium, titanium, copper, vanadium, iron, and zinc) had been reported to possess potentials antimicrobial activities (Ogunniran et al. 2008, Raman et al. 2001, Ejidike and Ajibade 2017, Bamigboye et al. 2017).

Organic ligands activities upon complexing with transition metals have displayed potent bacteriostatic activities, for example, the antimicrobial activities of nonsteroidal anti-inflammatory drugs
(NSAIDs) have been reported to improve upon complexation with metals and other coligands (Raman et al. 2001). Despite the therapeutic advantages of NSAIDs, several drawbacks have reduced their usage clinically. Thus, studies have reported their reduced negative side effects (Anacona et al. 2015, Maitera et al. 2018). A report has been issued that the use of $d$-block metal complexes of NSAIDs as therapeutic agents will reduce its side effects. This is a result of the anti-inflammatory properties of some $d$ block metal ions, such as $\mathrm{Cu}$ (II) and $\mathrm{Zn}$ (II) (Fraser et al. 1972, Ketan et al. 2012). This report for the first time evaluated the antimicrobial activities and anti-inflammatory agents of novel complexes of $\mathrm{Fe}^{2+}, \mathrm{Ni}^{2+}$, and $\mathrm{Cu}^{2+}$ coordinated with the NSAID salicylic acid. Synthesis and structural properties of copper(II) and nickel(II) complexes of the non-steroidal anti-inflammatory drug (NSAIDs) indomethacin comprising aromatic chelating $N, N$-donor ligand of the types $[\mathrm{Cu} \text { (indo })_{2}$ (phen) $\left.\left(\mathrm{H}_{2} \mathrm{O}\right)\right]$ and $[\mathrm{Ni} \text { (indo })_{2}($ phen $\left.)\left(\mathrm{H}_{2} \mathrm{O}\right)_{2}\right] \cdot 1.5 \mathrm{H}_{2} \mathrm{O}$ have been reported (Nnabuike et al. 2021).

The prominence of metal-based drug complexes obtained from the combination of metal ions to ligands is gaining ground in the design of chemotherapeutic drugs. Owing to the past studies on metal-based therapeutic intermediaries, preparations, and characterizations (Ejidike and Ajibade 2017, Bamigboye et al. 2017, 2020), this research work presents the synthesis, characterizations, and evaluation of the in vitro antibacterial activities of mixed Ibuprofen-Salicylic acid metal drug complexes.

\section{Materials and Methods}

The chemicals and reagents were of analytic grade purchased from Sigma-Aldrich and used without further purification. The ligands (Ibuprofen and Salicylic acid) were obtained from the Swiss Chemical Company, Lagos. The cultured organisms were collected from the Department of Microbiology, University of Ilorin. Atomic Absorption Spectrometer was used to analyze the metal contents of the complexes. The determination of the melting points of the complexes was 
performed using the Gallenkamp melting point apparatus. The elemental analysis was performed at Medac Limited, Brunel Science, Egham, United Kingdom. This is to determine the percentage composition of elements $(\mathrm{C}$, $\mathrm{H}$, and $\mathrm{N}$ ) present in the complexes. The functional groups present in the compounds were confirmed using a $\mathrm{KBr}$ disc on Shimadzu FTIR-8400S Fourier Transform Infrared Spectrophotometer. The Ultravioletvisible spectra of the complexes were recorded on a Jenway $6405 \mathrm{UV} / \mathrm{Vis}$ spectrophotometer within the range of 200 $800 \mathrm{~nm}$. The molar conductance was recorded on Jenway 4510 conductivity meter with a cell constant of 1.42 .

\section{Synthesis of complexes}

The complexes were synthesized according to the literature (Bamigboye et al. 2020). Briefly, Ibuprofen $(0.21 \mathrm{~g}, 1 \mathrm{mmol})$ was dissolved in $20 \mathrm{ml}$ of ethanol; similarly, salicylic acid (0.14 g, $1 \mathrm{mmol})$, metal ions (1 mmol) were weighed and dissolved in $20 \mathrm{ml}$ of ethanol separately. The mixed solution of ibuprofen and salicylic acid was added quantitatively into the metal ion solution separately. The individual solution was carefully swirled to have a uniform mixture. The mixture was then refluxed for $3 \mathrm{~h}$. It was left to cool and immediately precipitate began to form. The precipitate was collected, washed, and recrystallized from ethanol, and dried in a desiccator. The dried complexes obtained were transferred into a labelled sample bottle for further analysis.

\section{Antimicrobial activities}

Procedures reported in the literature (Bamigboye et al. 2017) were adopted to evaluate the antimicrobial activities of the complexes. Seven grams of nutrient agar were weighed and dissolved into $250 \mathrm{ml}$ of distilled water in a conical flask. Cotton wool and aluminium foil were used to covert the content of the flask before autoclaving. The selected microbes (K. pneumonia, B. subtilis, E. coli, $S$. aureus, $P$. aeroginosa and $S$. faecalis) were inoculated on top of the prepared agar which has been solidified in the
Petri dish. About $5 \mathrm{~mm}$ of sterilized cork borer was used to drill holes at the middle of the agar plate at concentrations of $20 \mathrm{ppm}$ for all the complexes in solution. They were transferred into the drilled holes, and plates allowed to stand for $30 \mathrm{~min}$ to ensure proper penetration of the test compounds before incubating at $37{ }^{\circ} \mathrm{C}$ for $24 \mathrm{~h}$. Zones of inhibition (mm) were measured and recorded.

\section{Results and Discussion \\ Chemistry of the compounds}

The synthesized complexes were obtained in good quantitative yields; $78.5 \%$ for iron complex $\left(\mathrm{C}_{20} \mathrm{H}_{21} \mathrm{Cl}_{2} \mathrm{FeO}_{5}, 468.13 \mathrm{~g} / \mathrm{mol}\right)$, $88.9 \%$ for copper complex $\left(\mathrm{C}_{20} \mathrm{H}_{21} \mathrm{CuO}_{5} \mathrm{Cl}_{2}\right.$, $475.83 \mathrm{~g} / \mathrm{mol}), 80.3 \%$ for nickel complex $\left(\mathrm{C}_{20} \mathrm{H}_{21} \mathrm{NiO}_{5} \mathrm{Cl}_{2}, 470.98 \mathrm{~g} / \mathrm{mol}\right)$. The complexes were in powdery form, coloured, and stable to air. The colour is as a result of $d$ $d$ transitions due to partial filled $d$-orbital of each metal ions (Ejidike 2018). The synthesized complexes are very stable due to their polydentate nature. The elemental analysis of the complexes is presented in Table 1. According to the results, it was observed that the theoretical values are in good agreement and compete favourable to the experimental value, this indicates successful coordination of the ligands to the metal ions. The proposed structure of the Ibuprofen-Salicylic acid metal(II) complexes are shown in Figure. 1. The physicochemical properties of the parent ligands and their complexes are shown in Table 1. The conductivity of iron, nickel, and copper complexes were found to be 12.4, 13.6, and $11.8 \Omega^{-1} \mathrm{~cm}^{2} \mathrm{~mol}^{-1}$, respectively. Since the molar conductance of the synthesized complexes were less than $40 \Omega^{-1} \mathrm{~cm}^{2} \mathrm{~mol}^{-1}$, they are non-electrolytic in nature (Ejidike and Ajibade 2017). The melting points of Salicylic acid and Ibuprofen were observed to be $74-76{ }^{\circ} \mathrm{C}$ and $157-159{ }^{\circ} \mathrm{C}$, respectively, the new complexes melting points were found higher than their parent-free ligand, the melting points for iron, nickel, and copper complex were found to be $191-192{ }^{\circ} \mathrm{C}, 183-$ $185^{\circ} \mathrm{C}$, and $181-182^{\circ} \mathrm{C}$, respectively. 
Table 1: Physicochemical properties of the ligands and complexes

\begin{tabular}{|c|c|c|c|c|c|c|c|}
\hline \multirow{2}{*}{$\begin{array}{l}\text { Ligand/ } \\
\text { Complexes }\end{array}$} & \multirow{2}{*}{$\begin{array}{l}\text { Conductivity } \\
\left(\Omega^{-1} \mathrm{~cm}^{2}\right. \\
\left.\mathrm{mol}^{-1}\right)\end{array}$} & \multirow{2}{*}{$\begin{array}{l}\text { Melting } \\
\text { point } \\
\left({ }^{\circ} \mathrm{C}\right)\end{array}$} & \multicolumn{5}{|c|}{ Experimental/Theoretical (\%) } \\
\hline & & & $\mathrm{C}$ & $\mathrm{H}$ & $\mathrm{N}$ & $\mathrm{Cl}$ & M \\
\hline $\begin{array}{l}\text { Salicylic acid } \\
{[\text { Sal] }}\end{array}$ & - & $74-76$ & - & - & - & - & - \\
\hline Ibuprofen [Ibu] & - & $157-159$ & - & - & - & - & - \\
\hline$\left[\mathrm{Fe}(\mathrm{Ibu})(\mathrm{Sal}) \mathrm{Cl}_{2}\right]$ & 12.4 & $191-192$ & $\begin{array}{l}50.96 \\
(50.43)\end{array}$ & $\begin{array}{l}5.14 \\
(5.32)\end{array}$ & $\begin{array}{l}7.04 \\
(7.98)\end{array}$ & $\begin{array}{l}15.13 \\
(15.44)\end{array}$ & $\begin{array}{l}11.9 \\
(10.98)\end{array}$ \\
\hline$[\mathrm{Ni}(\mathrm{Ibu})(\mathrm{Sal})] \mathrm{Cl}_{2}$ & 13.6 & $183-185$ & $\begin{array}{l}50.71 \\
(50.01)\end{array}$ & $\begin{array}{l}5.16 \\
(5.78)\end{array}$ & $\begin{array}{l}16.95 \\
(16.77)\end{array}$ & $\begin{array}{l}15.02 \\
(14.97)\end{array}$ & $\begin{array}{l}12.47 \\
(12.29)\end{array}$ \\
\hline$[\mathrm{Cu}(\mathrm{Ibu})(\mathrm{Sal})] \mathrm{Cl}_{2}$ & 11.8 & $181-182$ & $\begin{array}{l}50.15 \\
(50.37)\end{array}$ & $\begin{array}{l}5.05 \\
(5.49)\end{array}$ & $\begin{array}{l}16.72 \\
(16.38)\end{array}$ & $\begin{array}{l}14.81 \\
(14.59)\end{array}$ & $\begin{array}{l}13.37 \\
(13.54)\end{array}$ \\
\hline
\end{tabular}

The sign - means no activity.

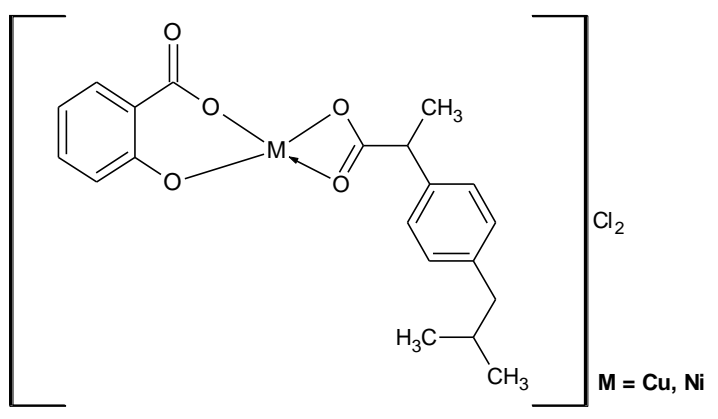<smiles></smiles>

Figure 1: Proposed structure of the metal complexes.

\section{Infrared absorption spectra}

The infrared spectra of the synthesized complexes and their ligands are presented in Figure 2. The characteristic functional groups bands of the parent ligands were compared to those of the synthesized complexes. A band at $1728 \mathrm{~cm}^{-1}$ is attributed to $v(\mathrm{C}=\mathrm{O})$ vibration in the
Ibuprofen [Ibu] and shifted to higher frequencies in the metal complexes $v\left(1740-1757 \mathrm{~cm}^{-1}\right)$ upon coordination. The broad $v(\mathrm{O}-\mathrm{H})$ bands at $3315 \mathrm{~cm}^{-1}$ and 3325 $\mathrm{cm}^{-1}$ in the ligands was very weak in the synthesized complexes (nickel-, copper-, and iron-complexes) and shifted to higher frequencies, these could be attributable to the transformation of the functional groups upon coordination (Raman et al. 2001, Ejidike and Ajibade 2017, Bamigboye et al. 2017). The hydrogen atom on the $\mathrm{OH}$ group was lost, and a metal-oxygen atom was formed $v(-\mathrm{C}-\mathrm{O}-\mathrm{M})$.

Since the metal-oxygen bond is weak, it was observed in the region $443-476 \mathrm{~cm}^{-1}$ in the complexes assigned to $v(\mathrm{M}-\mathrm{O})$ stretching vibrations (Ejidike and Ajibade 2017). These absorptions in all the complexes confirmed the coordination of the metal ion via the carboxylate group of the Ibuprofen ligand and hydroxyl ion of both the carboxylic and phenolic groups in salicylic acid ligands (Raman et al. 2001, Bamigboye et al. 2017, Ejidike 2018). Another new band at $416 \mathrm{~cm}^{-1}$ appeared in the $\left[\mathrm{Fe}(\mathrm{Ibu})(\mathrm{Sal}) \mathrm{Cl}_{2}\right]$ complex due to $v(\mathrm{M}-$ $\mathrm{Cl})$ vibrations, confirming the coordination of the chloride ion to the central metal ions (Arish and Nair 2010, Shakir et al. 2017). 


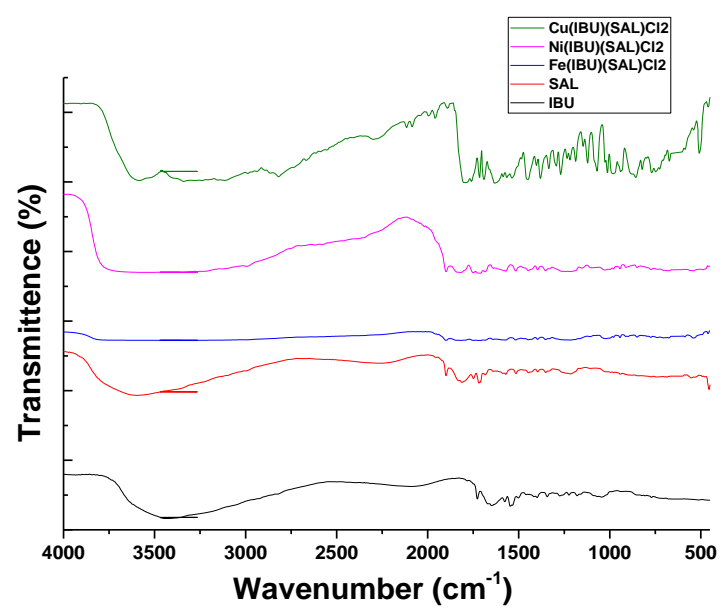

Figure 2: Infrared spectra of the ligands and their complexes.

\section{UV-visible absorption}

The ultraviolet-visible spectra of the ligands and the complexes are indicated in Figure 3. The free ligands showed absorption bands around 213-217 $\mathrm{nm}$ attributable to intraligand $\pi-\pi^{*}$ and $n-\pi^{*}$ transitions which undergo a hypochromic shift to higher frequencies (215-238 nm) in nickel complex (Chohan and Kausar 2000, Ejidike and Ajibade 2015, Bamigboye et al. 2017). The UV spectrum of $[\mathrm{Ni}(\mathrm{Ibu})(\mathrm{Sal})] \mathrm{Cl}_{2}$ complex showed a broadband between $392-416 \mathrm{~nm}$ which are assigned to ${ }^{1} \mathrm{~A}_{1 \mathrm{~g}} \rightarrow{ }^{1} \mathrm{~A}_{2 \mathrm{~g}}$ and ${ }^{1} \mathrm{~A}_{1 \mathrm{~g}} \rightarrow{ }^{1} \mathrm{~B}_{1 \mathrm{~g}}$ transitions for $\mathrm{Ni}$ (II) complex in a square planar geometry (Ejidike and Ajibade 2017). The synthesized copper complex also showed characteristic low intensity two broad peaks between $212-240 \mathrm{~nm}$ and $250-287 \mathrm{~nm}$, due to aromatic $\pi-\pi^{*}$ and $\mathrm{n}-\pi^{*}$ transitions, respectively, however, these absorption bands shifted to higher wavenumbers with increased intensity, while absorption of a broad lowintensity band in the regions $445 \mathrm{~nm}$ was attributed to ${ }^{2} \mathrm{~B}_{1 \mathrm{~g}} \rightarrow{ }^{2} \mathrm{~A}_{1 \mathrm{~g}}$ transition associated with metals having $d$-orbitals of a square planar copper(II) complex (Raman et al. 2001, Ejidike and Ajibade 2017, Ejidike 2018). The new Ibuprofen-Salicylic acid-iron complex $\left[\mathrm{Fe}(\mathrm{Ibu})(\mathrm{Sal}) \mathrm{Cl}_{2}\right]$ featured a lowintensity broad band with a peak at about 225 $\mathrm{nm}$ indicating the presence of $n-\pi *$ interactions for the aromatic system in the complex. Overall, the electronic transitions for iron(III) systems are spin forbidden and henceforth weak and are frequently marked by charge transfer bands (Shabani et al. 2010). The spectra data of the $\left[\mathrm{Fe}(\mathrm{Ibu})(\mathrm{Sal}) \mathrm{Cl}_{2}\right]$ showed one band at $438 \mathrm{~nm}$ (Figure 3) assignable to ${ }^{6} \mathrm{~A}_{1 \mathrm{~g}} \rightarrow{ }^{4} \mathrm{~T}_{1 \mathrm{~g}}$ transition, which is a characteristic of an octahedral structure (Shabani et al. 2010). From the coordination point of view and structure of the synthesized complexes, it has been suggested that the copper and nickel complexes possess square planar geometry, while the iron complex exhibited an octahedral geometry.

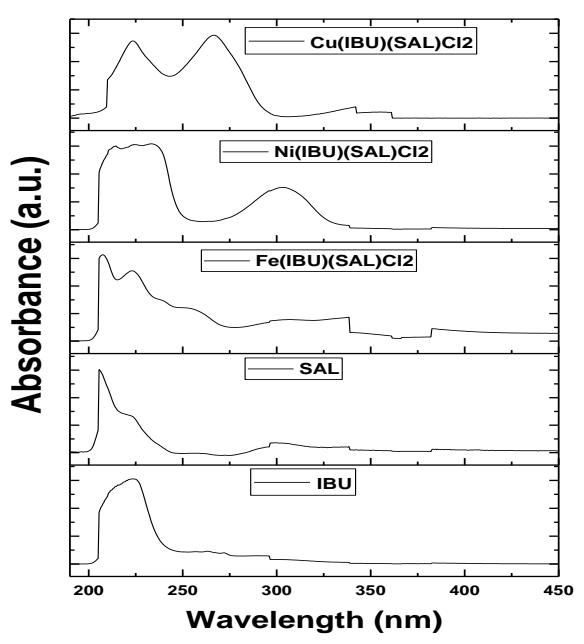

Figure 3: UV-visible spectra of the ligands and their complexes. 


\section{X-ray diffraction spectra}

The powder X-ray diffraction spectra of the synthesized coordinated complexes are presented in Figures 4 a-c. The sharp peak observed in the complexes indicated the crystallinity nature of the complexes (Ejidike 2018). The powdered XRD is a reliable dependable technique to dictate structural information of the coordinated complexes and nanomaterials at wavelength $1.5406 \AA$. The data of $\sin 2 \mathrm{~d}$ for each of the peaks have been reported by cell parameters and the $\mathrm{h}, \mathrm{k}, \mathrm{l}$ values. $D=0.9 \lambda /(\beta \cos \theta) \cdot \theta=$ is Bragg diffraction angle. $\beta=$ Full width at half maximum of the diffraction peak. The complexes have an average of 57,61, and 52 $\mathrm{nm}$ crystallite sizes for $\left[\mathrm{Fe}(\mathrm{Ibu})(\mathrm{Sal}) \mathrm{Cl}_{2}\right]$, $[\mathrm{Ni}(\mathrm{Ibu})(\mathrm{Sal})] \mathrm{Cl}_{2}$, and $[\mathrm{Cu}(\mathrm{Ibu})(\mathrm{Sal})] \mathrm{Cl}_{2}$ complexes, respectively (Ejidike and Ajibade 2015).
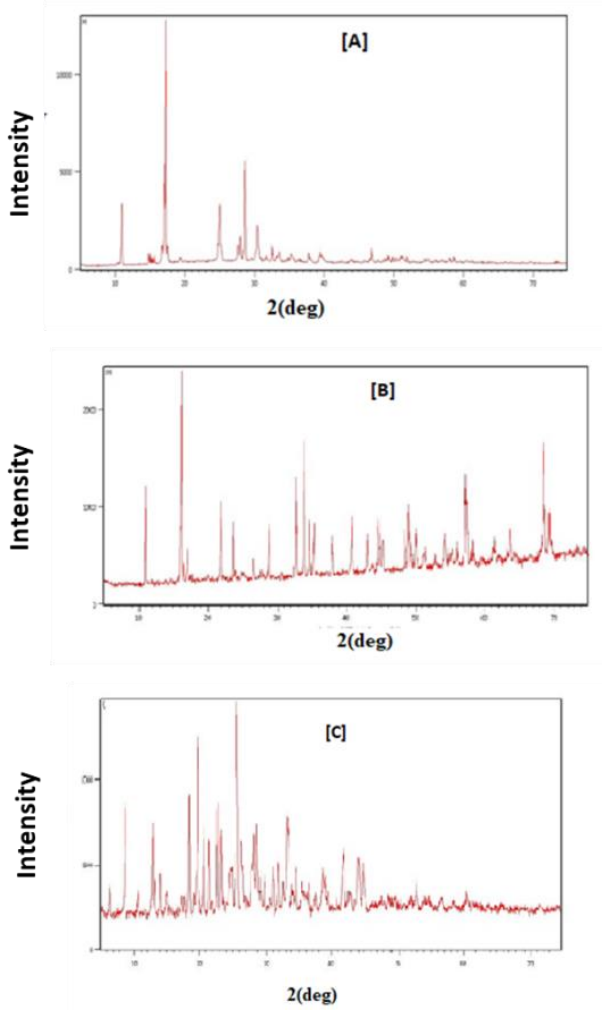

Figure 4: Powder X-ray diffraction patterns of the metal complexes: (a) $\left[\mathrm{Fe}(\mathrm{Ibu})(\mathrm{Sal}) \mathrm{Cl}_{2}\right]$,
(b)
$[\mathrm{Ni}(\mathrm{Ibu})(\mathrm{Sal})] \mathrm{Cl}_{2}$
and
(c)

\section{Antimicrobial activities}

The antimicrobial activities of the free ligands and their synthesized complexes are shown in Table 2. Both the ligands and the complexes were screened against some selected gram-positive bacteria ( $S$. aureus, $B$. subtilis, and $S$. faecalis) and gram-negative bacteria (K. pneumonia, E. coli, and $P$. aeroginosa). Based on the results, the synthesized complexes exhibited higher inhibitory effects than their parent-free ligands against gram-positive and negative bacteria. The increased antibacterial activities of the complexes upon complexation when compared with the parent ligand could be as a result of the positive charges present in the metal ions which improve the solubility mechanism of the chelate compounds (David et al. 2005, Liu et al. 2013, Ejidike and Ajibade 2015). Gram-positive bacteria have a thicker peptidoglycan cell wall compared to gram-negative counterparts. The former contains thick peptidoglycan and teichoic acid, while the latter contains a thin peptidoglycan cell wall with no teichoic acid (de Pedro and Cava 2015). One major setback for antibiotics against gram-negative bacteria is the need for the drugs to cross the outer membrane, which is impermeable by many antibiotics. The use of nutrient-import transporters to transport the antibiotics is becoming a new therapeutic approach for bacterial infection treatment (Schalk 2018).

Table 2 shows that the iron-containing complex $\left[\mathrm{Fe}(\mathrm{Ibu})(\mathrm{Sal}) \mathrm{Cl}_{2}\right]$ was found to show more activities in three bacterial variants (zone of inhibition): K. pneumonia (26.45 $\mathrm{mm}), S$. aureus $(23.98 \mathrm{~mm})$ which are gramnegative bacteria and $B$. subtilis $(21.67 \mathrm{~mm})$ a gram-positive bacteria; exhibiting higher inhibitory effects when compared to copper or nickel-containing complexes. The higher activities of iron-containing complex are due to its importance in bacterial growth. The uptake of iron by bacteria follows the siderophore-dependent. Siderophores are small organic chelators generated by bacteria to scavenge iron from their environment and transport it to the bacterial cytoplasm through special uptake pathways that involve specific outer-membrane transporters in gram- 
negative bacteria (Schalk et al. 2012). The antibiotics use the siderophore as a Trojan horse to access the ferrisiderophore uptake transporters to enter into the bacteria. Thus, potential antibiotic complexes containing iron metal such as the $\left[\mathrm{Fe}(\mathrm{Ibu})(\mathrm{Sal}) \mathrm{Cl}_{2}\right]$ complex will increase the uptake of the drug by the bacteria and hence, more activities as confirmed in our results.

The $\left[\mathrm{Cu}(\mathrm{Ibu})(\mathrm{Sal}) \mathrm{Cl}_{2}\right]$ complex showed a high zone of inhibition in two-gram negative bacteria; E. coli and P. aeroginosa, $45.10 \mathrm{~mm}$ and $23.34 \mathrm{~mm}$, respectively. Copper is an important biometal for preparing metal-based drugs due to the strong potential for therapeutic applications (Duncan and White 2012). The mechanism of the cytotoxicity of copper against bacterial growth is probably due to the redox cycling reactions between $\mathrm{Cu}$ (II) and $\mathrm{Cu}(\mathrm{I})$ oxidation states that lead to the formation of reactive radical species. The reactive radical species under aerobic conditions produce highly reactive free hydroxyl radicals which react with its immediate environment within the cell including membrane lipids, proteins, and nucleic acids to generate different dangerous species and products. This reaction results in the damage of the bacterial DNA (Čongrádyová et al. 2014). The result is in line with what was reported by Duncan and
White 2012, who showed that copper salicylate ligand exhibited higher antibacterial activities against $E$. coli compared to the free ligand. The strong inhibitory effect of the synthesized $\quad\left[\mathrm{Cu}(\mathrm{Ibu})(\mathrm{Sal}) \mathrm{Cl}_{2} \quad\right.$ complex against E. coli and P. aeroginosa showed it could be a potential antibiotic against other gram-negative bacteria.

Nickel-containing complex showed the highest inhibitory effect against $S$. faecalis bacteria, with $23.87 \mathrm{~mm}$ zone of inhibition compared to iron and copper-containing complex which showed 16.78 and $18.42 \mathrm{~mm}$ zones of inhibition, respectively. Nickel is an important metal in medicinal inorganic chemistry, because of its characteristics antimicrobial properties. It has the potential to penetrate microbial cells and destroy the microorganisms by inactivating their enzymes (Chohan and Kausar 2000). Nickel-containing ligand has been reported in the literature (Popova 2012) to show high activity against $S$. faecalis a gram-positive bacteria and very weak activity against $E$. Coli a gram-negative bacteria, the synthesized $[\mathrm{Ni}(\mathrm{Ibu})(\mathrm{Sal})] \mathrm{Cl}_{2}$ complex showed similar trend. The antimicrobial activities confirmed that the complexes have higher medicinal therapeutic potential against the activities of organisms than their free ligands (Ejidike et al. 2015).

Table 2: Antimicrobial activities of the ligands and complexes

\begin{tabular}{|c|c|c|c|c|c|c|}
\hline \multirow[t]{2}{*}{ Ligands/Complexes } & K. pneumonia & $\begin{array}{c}\text { B. } \\
\text { subtilis }\end{array}$ & E. coli & $\begin{array}{c}\text { S. } \\
\text { aureus }\end{array}$ & $\begin{array}{c}P . \\
\text { aeruginosa }\end{array}$ & $\begin{array}{c}S . \\
\text { faecalis }\end{array}$ \\
\hline & \multicolumn{6}{|c|}{ Zone of inhibition (mm) } \\
\hline Salicylic acid [Sal] & - & - & - & - & - & - \\
\hline Ibuprofen [Ibu] & 2 & - & - & 5 & - & - \\
\hline$\left[\mathrm{Fe}(\mathrm{Ibu})(\mathrm{Sal}) \mathrm{Cl}_{2}\right]$ & 26.45 & 21.67 & 34.53 & 23.98 & 11.43 & 16.78 \\
\hline$[\mathrm{Ni}(\mathrm{Ibu})(\mathrm{Sal})] \mathrm{Cl}_{2}$ & 17.43 & 11.96 & 14.86 & 15.23 & 17.38 & 23.87 \\
\hline$[\mathrm{Cu}(\mathrm{Ibu})(\mathrm{Sal})] \mathrm{Cl}_{2}$ & 17.65 & 18.20 & 35.10 & 19.45 & 23.34 & 18.45 \\
\hline
\end{tabular}

Key: $K=$ Klebsiella, $B=$ Bacillus, $E=$ Escherichia, $S=$ Staphylococcus, $P=$ Pseudomonas, $S$ $=$ Streptococcus, and $-=$ no activity.

\section{Conclusion}

The metal complexes of $\mathrm{Cu}^{2+}, \mathrm{Ni}^{2+}$, and $\mathrm{Fe}^{2+}$ have been synthesized and coordinated via the oxygen donor atoms of the ligands in a stoichiometric ratio of $1: 1: 1$ giving rise to $\left[\mathrm{Fe}(\mathrm{Ibu})(\mathrm{Sal}) \mathrm{Cl}_{2}\right], \quad[\mathrm{Ni}(\mathrm{Ibu})(\mathrm{Sal})] \mathrm{Cl}_{2}, \quad$ and $[\mathrm{Cu}(\mathrm{Ibu})(\mathrm{Sal})] \mathrm{Cl}_{2}$. The complexes were characterized via elemental analyzer, conductivity, UV-vis, FT-IR, and XRD. In the UV-vis analysis, $[\mathrm{Ni}(\mathrm{Ibu})(\mathrm{Sal})] \mathrm{Cl}_{2}$ and $[\mathrm{Cu}(\mathrm{Ibu})(\mathrm{Sal})] \mathrm{Cl}_{2}$ complexes were suggested to possess square planar geometries, while the $\left[\mathrm{Fe}(\mathrm{Ibu})(\mathrm{Sal}) \mathrm{Cl}_{2}\right]$ exhibited an octahedral geometry. The conductivity measurements value suggests that the complexes are nonelectrolyte. The FT-IR data suggests the 
ligand acts as bidentate and forms complexes through the carboxylate group of the ibuprofen ligand and hydroxyl ion of both the carboxylic and phenolic groups in salicylic acid ligands. The XRD study suggests metal complexes possess a well-defined crystalline structure with average crystallite sizes of $<62$ $\mathrm{nm}$. The biological evaluation results showed the complexes exhibited better antimicrobial properties as compared to the free ligand against some selected organisms (K. pneumonia, B. subtilis, E. coli, S. aureus, $P$. aeruginosa, and $S$. faecalis). The compounds showed a broad spectrum of anti-biological activities supporting their usage for the development of chemotherapeutic agents.

\section{Acknowledgments}

The authors wish to express their gratitude to the technical staff of the Department of Biological Sciences, University of Ilorin, Ilorin, Nigeria, Directorate of Research, University of South Africa, Florida campus, and National Research Foundation (Grant No: 120790), South Africa.

Competing Interest: The authors declare no competing interest regarding this study.

\section{References}

Aisen P, Enns C and Wessling-Resnick M 2001 Chemistry and biology of eukaryotic iron metabolism. Int. J. Biochem. Cell Biol. 33(10): 940-959.

Anacona JR, Noriega N and Camus J 2015 Synthesis, characterization and antibacterial activity of a tridentate Schiff base derived from ceptalthin and sulphadiazine and its transition metal complex. Spectrochim. Acta A Mol. Biomol. Spectrosc. 137: 16-22.

Andreini C, Bertini I, Cavallaro G, Holliday GL and Hornton JM 2008 Metal ions in biological catalysis: from enzyme databases to general principles. J. Biol. Inorg. Chem. 13(8): 1205-1218.

Arish D and Nair MS 2010 Synthesis, characterization, antimicrobial, and nuclease activity studies of some metal Schiff-base complexes. J. Coord. Chem. 63(9): 16191628.

Bamigboye MO, Anibijuwon II and Ajiboye AE 2017 Chelation, characterization, and antimicrobial studies of mixed nicotinamidecloxacillin metal complexes. Nig. J. Pure \& Appl. Sci. 30(2): 3007-3013.

Bamigboye OM, Ejidike IP, Ahmed RN, Lawal M, Nnabuike GG and Medubi K 2020 Chelation, characterization, and antibacterial activities of some mixed isonicotinic acid hydrazide-Paracetamol metal drug complexes. Suranaree J. Sci. Technol. 27(3): 030026-030029.

Barrios AM, Cohen SM and Lim MH 2013 Medicinal inorganic chemistry: A web themed issue. Chem. Commun. 49: 59105911.

Basak S, Singh P and Rajurkar M 2016 Multidrug resistant and extensively drug resistant bacteria: a study. J. Pathog. 2016: 4065603.

Chohan ZH and Kausar S 2000 Synthesis, characterization, and biological properties of tridentate NNO, NNS and NNN donor thiazole-derived furanyl, thiophenyl and pyrrolyl Schiff bases and their Co(II), $\mathrm{Cu}(\mathrm{II}), \mathrm{Ni}(\mathrm{II})$ and $\mathrm{Zn}(\mathrm{II})$ metal chelates. Met. Based Drugs 7(1): 17-22.

Čongrádyová A, Jomová K, Kucková L, Kožíšek J, Moncol' J and Valko M 2014 Antimicrobial activity of copper(II) complexes. J. Microbiol. Biotech. Food Sci. 3(1): 67-70.

David S, Barros V, Cruz C and Delgado R 2005 In vitro effect of free and complexed indium(III) against Mycobacterium tuberculosis. FEMS Microbiol. Lett. 251(1): 119-124.

Duncan C and White AR 2012 Copper complexes as therapeutic agents. Metallomics 4: 127-138.

Ejidike IP $2018 \mathrm{Cu}$ (II) complexes of 4-[(1E)- $N$ $\{2-[(Z)$-Benzylidene-amino] ethyl $\}$ ethanimidoyl]benzene-1,3-diol Schiff base: synthesis, a spectroscopic, in-vitro antioxidant, antifungal and antibacterial studies. Molecules 23(7): 1581.

Ejidike IP and Ajibade PA 2015 Synthesis, characterization and biological studies of metal(II) complexes of $(3 E)-3-[(2-\{(E)-[1-$ (2,4-dihydroxyphenyl) ethylidene] amino \}ethyl) imino]-1-phenylbutan-1-one Schiff base. Molecules 20(6): 9788-9802.

Ejidike IP and Ajibade PA 2017 Synthesis, spectroscopic, antibacterial and free radical scavenging studies of $\mathrm{Cu}(\mathrm{II}), \mathrm{Ni}(\mathrm{II}), \mathrm{Zn}$ (II) and $\mathrm{Co}$ (II) complexes of 4,4'-\{ethane-1,2- 
diylbis[nitrilo(1E)eth-1-yl-1-ylidene]\} dibenzene 1,3-diol Schiff base. J. Pharm. Sci. Res. 9(7): 593-600.

Florea AM and Büsselberg D 2011 Cisplatin as an anti-tumor drug: cellular mechanisms of activity, drug resistance and induced side effects. Cancers (Basel) 3(1): 1351-1371.

Fraser PM, Doll R, Langman MJS, Misiewicz JJ and Shawdon HH 1972 Clinical trial of a new carbenoxolone analogue (bx24), zinc sulphate and vitamin $\mathrm{A}$ in the treatment of gastric ulcer. Gut. 13(6): 459-463.

Frezza M, Hindo S, Chen D, Davenport A, Schmitt S, Tomco D and Ping Dou Q 2010 Novel metals and metal complexes as platforms for cancer therapy. Curr. Pharm. Des. 16(16): 1813-1825.

Graf N and Lippard SJ 2012 Redox activation of metal-based prodrugs as a strategy for drug delivery. Adv. Drug Delivery Rev. 64(11): 993-1004.

Ketan SP, Jiten CP, Hitesh RD, Patel VK and Patel KD 2012 Synthesis of $\mathrm{Cu}(\mathrm{II}), \mathrm{Ni}(\mathrm{II})$, $\mathrm{Co}(\mathrm{II})$ and $\mathrm{Mn}(\mathrm{II})$ complexes with ciprofloxacin and their evaluation of the antimicrobial, antioxidant and antituberculosis activity. Open J. Met. 2(3): 49-59.

Liu LX, Wax XQ, Yan JM, Li Y, Sun CJ, Chen W, Zhou B, Zhang HB and Yang XD 2013 Synthesis and antitumor activities of novel dibenzo[ $b, d]$ furan-imidazole hybrid compounds. Eur. J. Med. Chem. 66: 423437.

Maitera ON, Louis H, Barminas JT, Akakuru OU and Boro G 2018 Synthesis and characterization of some metal complexes using herbal flavonoids. Nat. Prod. Chem. Res. 6(3): 314.

Mjos KD and Orvig C 2014 Metallodrugs in medicinal inorganic chemistry. Chem. Rev. 114(8): 4540-4563.

Ndagi U, Mhlongo N and Soliman ME 2017 Metal complexes in cancer therapy-an update from drug design perspective. Drug Des. Dev. Ther. 11: 599-616.

Nnabuike GG, Salunke-Gawali S, Patil AS, Butcher RJ, Lawal M, Bamigboye MO and Obaleye JA 2021 Copper(II) and nickel(II) complexes of the non-steroidal antiinflammatory drug indomethacin containing aromatic chelating $\mathrm{N}, \mathrm{N}$-donor ligand:
Synthesis and structural studies. J. Mol. Struct. 1224: 129069.

Ogunniran KO, Ajanaku KO, James OO, Ajani OO, Nwinyi CO, Omonhimin $\mathrm{CA}$ and Allensela MA 2008 Synthesis, physical properties, antimicrobial potentials of some antibiotics complexed with transition metals and their effects on alkaline phosphate activities of selected rat tissues. Sci. Res. Essay 3(8): 348-354.

de Pedro MA and Cava F 2015 Structural constraints and dynamics of bacterial cell wall architecture. Front. Microbiol. 6: 449.

Popova TP, Alexandrova RI, Tudose R, Mosoarca EM and Costisor O 2012 Antimicrobial activity and in vitro of four nickel complexes. Bulg. J. Agric. Sci. 18(3): 446-450.

Raman N, Raja YP and Kulandaisamy A 2001 Synthesis and characterisation of $\mathrm{Cu}(\mathrm{II})$, $\mathrm{Ni}(\mathrm{II}), \mathrm{Mn}(\mathrm{II}), \mathrm{Zn}$ (II) and VO(II) Schiff base complexes derived from $o$ phenylenediamine and acetoacetanilide. $J$. Chem. Sci. 113(3): 183-189.

Schalk IJ 2018 Siderophore-antibiotic conjugates: exploiting iron uptake to deliver drugs into bacteria. Clin. Microbiol. Infect. 24(8): 801-802.

Schalk IJ, Mislin GL and Brillet K 2012 Structure, function and binding selectivity and stereoselectivity of siderophore-iron outer membrane transporters. Curr. Top. Membr. 69: 37-66.

Shabani F, Saghatforoush LA and Ghammamy S 2010 Synthesis, characterization and antitumour activity of iron(III) Schiff base complexes with unsymmetric tetradentate ligands. Bull. Chem. Soc. Ethiop. 24(2): 193199.

Shakir M, Hanif S, Alam MF, Farhan M and Younus H 2017 Hybrid pharmacophore approach for bio-relevant di-imines based homobimetallic complexes incorporating functionalized dicarboxylates as co-ligands: Synthesis, spectral and structural activity dependent biological insights (in-vitro DNA and HSA binding, antioxidant and cytotoxicity). J. Photochem. Photobiol. B: Biol 174: 106-125.

Storr T, Thompson KH and Orvig C 2006 Design of targeting ligands in medicinal inorganic chemistry. Chem. Soc. Rev. 35: 534-544. 